\title{
PENGARUH PENGGUNAAN MODEL KONTEKSTUAL TERHADAP KEMAMPUAN MENULIS TEKS PERSUASI SISWA KELAS VIII SMP MUHAMMADIYAH O5 MEDAN
}

\author{
Julita Simbolon $^{1}$, Hilman Haidir ${ }^{2}$, Ibrahim Daulay ${ }^{3}$ \\ Universitas Prima Indonesia ${ }^{1}$, Universitas Prima Indonesia ${ }^{2}$, Universitas Prima Indonesia ${ }^{3}$ \\ pos-el: julitasimbolon625@gmail.com¹, hilman_haidir3212@yahoo.co.id², \\ daulay.ibrahim@yahoo.co.id ${ }^{3}$
}

\begin{abstract}
ABSTRAK
Permasalahan data penelitian ini adalah (1) Kemampuan menulis teks persuasi masih tergolong rendah. (2) Rendahnya kemampuan menulis peserta didik diakibatkan model yang tidak tepat. (3) Peserta didik masih kesulitan menuangkan ide dalam menulis khususnya menulis teks persuasi. Penelitian ini bertujuan untuk mengetahui pengaruh model kontekstual terhadap kemampuan menulis teks persuasi oleh siswa kelas VIII SMP Muhammadiyah 05 Medan Tahun Pelajaran 2018/2019. Penelitian ini merupakan penelitian eksperimen dengan desain penelitian postest design. Penelitian ini menguji cobakan model pembelajaran kemudian mengetahui perbedaan penggunaannya atau meninjau pengaruh terhadap hasil belajar siswa. Populasi penelitian ini adalah semua siswa kelas VIII SMP Muhammaiyah 05 Medan Tahun Pelajaran 2018/2019 yang terdiri dari 2 kelas dengan jumlah 60 siswa. Alat pengumpulan data yang digunakan dalam penelitian ini adalah posttest design. Dari hasil penelitian dan pengelolaan data diperoleh kesimpulan ini, (1) rata-rata nilai kemampuan menulis teks persuasi siswa kelas VIII SMP Muhammadiyah 05 Medan Tahun Pelajaran 2018/2019 dengan menggunakan model konvensional adalah $=61,7$ dan yang menggunakan model kontekstual adalah $=80 .(2)$ rata-rata nilai kemampuan menulis teks persuasi oleh siswa kelas VIII SMP Muhammadiyah 05 Medan Tahun Pelajaran 2018/2019.
\end{abstract}

\section{Kata kunci : Model Kontekstual, Menulis Teks Persuasi, Eksperimen.}

\begin{abstract}
The problem of this research data is (1) the ability to write persuasion texts is still relatively low. (2) The low ability of students to write is caused by inappropriate models. (3) students still have difficulty in writing ideas in writing, especially writing persuasion texts. This study aims to determine the effect of contextual models on the ability to write persuasive texts by students of SMP VIII Muhammadiyah Middle School 05 Medan academic year 2018/2019. This research is an experimental study with a posttest design research design. This study examines the learning model and then discerns the differences in use or review the influence on student learning outcomes. The population of this study were all eighth grade students of Muhammadiyah Middle School 05 Medan 2018/2019 academic year consisting of 2 classes with 60 students the data collection tools used in this study were the design process. From the results of research and data management, this conclusion is obtained (1) the average value of the ability to write persuasive text in class VIII Muhammadiyah Middle School 05 Medan 2018/2019 academic year using the conventional model is $=61.7$ and using the contextual model is $=80$. (2) the average value of the ability to write persuasive texts by class VIII Muhammadiyah Middle School 05 Medan academic year 2018/2019.
\end{abstract}

Keywords: Contextual Model, Writing Persuasion Text, Experiments.

\section{PENDAHULUAN}

Bahasa memiliki peran penting dalam kehidupan manusia. Tanpa bahasa manusia tidak dapat berkomunikasi. Selain itu, bahasa juga berfungsi sebagai penunjang identitas bahasa Indonesia.
Pentingnya bahasa Indonesia dalam kehidupan manusia menjadikan bahasa tersebut dipelajari. Oleh sebab itu, bahasa Indonesia diajarkan di sekolah sejak sekolah dasar. Peranan dunia pendidikan 
harus mampu menghasilkan peserta didik yang terampil dalam berbahasa, baik di sekolah maupun masyarakat, menjadi keterampilan menyimak, berbicara, membaca, dan menulis.

Pada pembelajaran bahasa Indonesia, menulis merupakan salah satu di antara beberapa keterampilan berbahasa yang sangat penting karena menulis merupakan kegiatan berkomunikasi dengan menggunakan bahasa tulis. Dengan kata lain keterampilan berbahasa yang digunakan untuk berkomunikasi secara tidak langsung atau tidak secara tatap muka dengan orang lain. Menurut Marwoko (dalam Dalman, 1987:4) menjelaskan bahwa keterampilan menulis adalah mengungkapkan ide atau gagasannya dalam bentuk karangan secara leluasa.

Menulis teks persuasi merupakan salah satu aspek keterampilan berbahasa yang digunakan di sekolah dan salah satu standar kompetensi yang dicapai peserta didik. Meskipun demikian menunjukkan bahwa keterampilan menulis teks persuasif masih rendah. Hal ini diketahui dari pengalaman peneliti selama mengikuti praktik pengalaman lapangan (PPL).Rendahnya keterampilan menulis peserta didik dapat disebabkan oleh faktor dan salah satu diantaranya yaitu metode pembelajaran.

Begitu juga dalam proses pembelajaran agar dapat berhasil, sebagai pengajar, seorang guru hendaknya mampu menciptakan suasana yang lebih menarik dan tidak membosankan yaitu dengan kemampuannya merancang teknik pengajaran yang sesuai dengan menggunakan strategi dan model yang bervariasi sehingga dapat membangkit minat, memotivasi dan ketertarikan siswa dalam belajar khususnya bahasa Indonesia.

Model pembelajaran ini digunakan agar pembelajaran yang disampaikan guru dapat tercapai dan pembelajaran tidak membosankan serta guru pun dengan mudah menyalurkan informasi ke peserta didik sehingga merangsang pikiran, perasaan, perhatian, dan minat peserta didik yang pada akhirnya dapat menjadikan peserta didik melakukan kegiatan menulis. Pada kenyataannya penggunaan metode pembelajaran masih terabaikan dan model yang dibuat guru hanya monoton (Konvensional) sehingga membuat peserta didik jenuh dan bosan ,peserta didik sulit menuangkan ide dan gagasan dalam pikirannya ke dalam tulisan khusus pembelajaran menulis teks persuasif. Untuk itu model sangat diperlukan dalam proses belajar mengajar untuk meningkatkan kualitas peserta didik dan memotivasi serta menambah daya tarik peserta didik itu sendiri.

Dengan diterapkan model pembelajaran kontekstual dalam hubungannya dengan menulis teks persuasif dapat membantu daya nalar peserta didik untuk menjelaskan apa yang dilihat di sekitar lingkungannya sehari hari, memperhatikannya, pengalaman pengalaman yang dimilikinya, dan akhirnya dapat mengemukakan ide melalui fakta - fakta kemudian ditulis lewat kalimat yang dikembangkan menjadi teks persuasi. Dengan demikian model pembelajaran kontekstual sangat membantu guru untuk mengajar dan mengaitkan antara yang diajarkan guru dengan situasi dunia nyata peserta didik.

Agar penelitian ini mencapai sasaran, maka peneliti membatasi masalah yang diteliti. Melihat begitu luasnya ruang lingkup masalah yang teridentifikasi 
sehingga diperlukan pembatasan masalah. Batasan masalah dalam penelitian ini dibatasi pada pengaruh model kontekstual terhadap kemampuan menulis teks persuasi.

\section{Ciri-ciri teks persuasi}

Menurut Finoza (dalam Saripah, 2015: 17) mengemukakan ciri-ciri persuasi yaitu:

a. Berisi ajakan atau pengaruh secara langsung mengenai suatu hal sehingga dapat membuat pembaca/orang lain bergerak untuk melakukan sesuatu sebagaimana yang dikehendaki penulis.

b. Bertujuan untuk meyakinkan sekaligus mempengaruhi orang lain agar memiliki pemikiran atau melakukan sesuatu seperti kehendak penulis.

c. Terdapat fakta-fakta yang relevan dan jelas diuraikan sedemikian rupa sehingga kesimpulannya dapat diterima secara meyakinkan.

d. Persuasif berpengaruh kuat terhadap emosi atau perasaan pembaca.

\section{Teknik-teknik teks persuasi}

Menurut Keraf (2000: 124) teknikteknik atau metode-metode yang harus dipergunakan untuk mengadakan teks persuasif yaitu:

\section{a. Rasionalisasi}

Rasionalisasi sebenarnya tidak lain dari suatu argumentasi semu, suatu proses pembuktian mengenai suatu kebenaran dalam bentuknya yang agak lemah, dan biasanya diperlukan dalam persuasi.

b. Identifikasi

Identifikasi merupakan kunci keberhasilan pembicara, bila terdapat situasi konflik antar pembicara dan hadirin, maka pembicara harus berusaha mengaburkan situasi konflik terebut.

c. Sugesti

Sugesti adalah suatu usaha membujuk atau mempengaruhi orang lain untuk menerima suatu keyakinan atau pendirian tertentu tanpa memberi suatu dasar kepercayaan yang logis pada orang yang ingin dipengaruhi.

d. Konformitas

Konformitas adalah suatu keinginan atau suatu tindakan untuk membuat diri serupa dengan sesuatu hal yang lain.

e. Kompensasi

Kompensasi adalah suatu tindakan atau suatu hasil dari usaha untuk mencari suatu pengganti (substitut) bagi sesuatu hal yang tak dapat diterima atau suatu sikap atau keadaan yang tidak dapat dipertahankan.

f. Penggantian

Penggantian (displacement) adalah suatu proses yang berusaha menggantikan suatu maksud atau hal yang mengalami rintangan dengan suatu maksud atau hal lain yang sekaligus juga menggantikan emosi kebencian asli, atau kadang-kadang emosi cinta kasih yang asli.

g. Proyeksi

Proyeksi adalah suatu teknik untuk menjadikan sesuatu yang tadinya adalah subjek menjadi objek.

\section{Model Pembelajaran Kontekstual}

Shoimin (2016: 41) menyatakan bahwa pembelajaran Kontekstual (contextual teaching and learning) merupakan suatu proses pembelajaran yang holistik dan bertujuan memotivasi siswa untuk memahami makna materi pelajaran yang dipelajarinya dengan 
mengaitkan materi tersebut dengan konteks kehidupan sehari-hari (konteks pribadi, sosial, dan kultural) sehingga siswa memiliki pengetahuan/keterampilan yang secara fleksibel dapat diterapkan (ditransfer) dari satu permasalahan ke permasalahan lainnya.

a. Kelebihan Model Kontextual

1) Pembelajaran kontekstual dapat menekankan aktivitas berpikir siswa secara penuh, baik fisik maupun mental.

2) Pembelajaran kontekstual dapat menjadikan siswa belajar bukan dengan menghafal, melainkan proses berpengalaman dalam kehidupan nyata.

3) Kelas dalam kontekstual bukan sebagai tempat untuk memperoleh informasi, melainkan sebagai tempat untuk menguji data hasil temuan mereka di lapangan.

4) Materi pelajaran ditentukan oleh siswa sendiri, bukan hasil pemberian dari orang lain.

b. Kekurangan Model Kontekstual

1) Penerapan pembelajaran kontekstual merupakan pembelajaran yang kompleks dan sulit dilaksanakan dalam konteks pembelajaran, selain juga membutuhkan waktu yang lama.

\section{METODE PENELITIAN}

Dalam sebuah penelitian metode sangat berperan penting agar tujuan yang diharapkan dapat tercapai dengan baik. Arikunto (2006: cara yang digunakan oleh peneliti dalam mengumpulkan data penelitiannya.

Peneliti ini menggunakan metode eksperimen dan pendekatan kuantitatif. Metode penelitian eksperimen dapat diartikan sebagai metode penelitian yang digunakan untuk mencari pengaruh perlakuan tertentu terhadap yang lain dalam kondisi yang terkendalikan (Sugiyono, 2013: 107). Metode eksperimen dilakukan untuk mengetahui secara pasti bagaimana pengaruh penggunaan model kontekstual terhadap kemampuan siswa dalam menulis teks persuasif. Jadi, dalam pelaksanaannya, kelas yang dieksperimenkan adalah yang ditentukan berdasarkan proses simple random sampling yaitu kelas VIII-1 dengan menggunakan model kontekstual dan kontrol yaitu VIII-2tanpa model kontekstual. Kedua kelompok tersebut diberi materi yang sama sesuai tahapan kegiatannya.

\section{HASIL DAN PEMBAHASAN}

Setelah peneliti melakukan pengumpulan data dari SMP Muhammadiyah 05 Medan, maka langkah selanjutnya adalah menganalisis data yang terkumpul. Penelitian ini merupakan penelitian yang melibatkan dua kelas yang diberi perlakuan yang berbeda yaitu kelas eksperimen dan kelas kontrol. Masingmasing siswa terdiri dari 30 siswa, satu kelas sebagai kelas eksperimen dan kelas yang lainnya sebagai kelas kontrol. Selama penelitian dilakukan semua sampel mengikuti seluruh kegiatan penelitian. Penelitian ini menggunakan metode eksperimen two group post-test design only. 
Berdasarkan hasil penelitian tersebut, maka dapat dicari Nilai Rata-rata, Standar deviasi, dan Standar eror pada kelas kontrol yaitu:

1. Rata-rata data post-test kelas

$$
\begin{aligned}
& \text { kontrol }\left(\mathrm{X}_{2}\right) \\
& \sum \mathrm{Xi}=1740 \\
& \sum \mathrm{X}^{2}=\mathbf{1 1 2 3 5 0} \\
& \overline{\mathrm{X}}=\frac{\sum X i}{n}
\end{aligned}
$$

Berdasarkan tabel tersebut, maka maka dapat dicari Nilai Rata-rata, Standar deviasi, dan Standar error pada kelas kontrol yaitu:

Berdasarkan hasil penelitian tersebut, maka dapat dicari Nilai Rata-rata, Standar deviasi, dan Standar eror pada kelas kontrol yaitu:

2. Rata-rata data post-test kelas kontrol $\left(\mathrm{X}_{2}\right)$

$$
\begin{array}{rlr}
\sum X \mathrm{X} & =1740 & \mathrm{n}=30 \\
\sum \mathrm{X}^{2} & =\mathbf{1 1 2 3 5 0} \\
\overline{\mathrm{X}} & =\frac{\sum X i}{n} \\
& =\frac{1740}{30} \\
& =61,7
\end{array}
$$

3. Standar deviasi data post-test kelas kontrol $\left(\mathrm{X}_{2}\right)$

$$
\begin{aligned}
& S=\sqrt{\frac{n\left(\sum X i^{2}\right)-\left(\sum X i\right)^{2}}{n(n-1)}} \\
& S=\sqrt{\frac{30(17043,5)-(1851)^{2}}{30(30-1)}} \\
& S=\sqrt{\frac{3511305-3426201}{870}} \\
& S=\sqrt{\frac{85104}{870}} \\
& S^{2}=\mathbf{9 7 , 8 2} \\
& S=\mathbf{9 , 8 9}
\end{aligned}
$$

$$
\begin{aligned}
& =\frac{1740}{30} \\
& =61,7
\end{aligned}
$$

4. Standar deviasi data post-test kelas kontrol $\left(\mathrm{X}_{2}\right)$

$$
\begin{aligned}
& S=\sqrt{\frac{n\left(\sum X i^{2}\right)-\left(\sum X i\right)^{2}}{n(n-1)}} \\
& S=\sqrt{\frac{30(17043,5)-(1851)^{2}}{30(30-1)}} \\
& S=\sqrt{\frac{3511305-3426201}{870}} \\
& S=\sqrt{\frac{85104}{870}} \\
& S^{2}=\mathbf{9 7 , 8 2} \\
& S=\mathbf{9 , 8 9}
\end{aligned}
$$

\section{KESIMPULAN}

Berdasarkan hasil analisis data dan uji statistik ditetapkan kesimpulan berikut ini: Kemampuan siswa dalam mengidentifikasi unsur-unsur teks puisi di kelas kontrol dengan menggunakan model ceramah diperoleh mean (rata-rata) 61.7 termasuk dalam Kategori Cukup (C).1 Maka dapat diketahui bahwa kemampuan menulis teks persuasi pada siswa termasuk kategori sangat baik 0 siswa atau $0 \%$, kategori baik sebanyak 7 siswa atau $27 \%$, kategori cukup sebanyak 17 siswa atau $57 \%$, kategori kurang sebanyak 6 siswa atau $18 \%$, dan kategori sangat kurang sebanyak 0 siswa atau $0 \%$. Identifikasi hasil post-test tersebut dalam kategori cukup.

Kemampuan menulis teks persuasi dengan menggunakan model kontekstual diperoleh mean (rata-rata) 82.5 termasuk dalam kategori B (Baik). Maka dapat diketahui bahwa kemampuan mengidentifikasi teks puisi termasuk kategori sangat baik sebanyak 11 siswa atau 37\%, kategori baik sebanyak 17 siswa atau 57\%, kategori cukup sebanyak 2 siswa atau $7 \%$, kategori kurang sebanyak 0 siswa atau $0 \%$, dan kategori sangat kurang sebanyak 0 siswa atau $0 \%$. 
Identifikasi hasil post-test tersebut dalam kategori baik.

Maka dapat diketahui bahwa thitung $>t_{\text {tabel }}$ yakni 8.35> 2,002. Dengan demikian, bila $t_{\text {hitung }}$ lebih besar dari $t_{\text {tabel }}$ berarti Ha diterima. Sehingga dapat disimpulkan bahwa model kontekstual memiliki pengaruh terhadap kemampuan menulis teks persuasi siswa kelas VIII SMP Swasta Muhammadiyah 05 Medan tahun pelajaran 2018/2019.

\section{DAFTAR PUSTAKA}

Arikunto, Suharsimi, 2010. Prosedur Penelitian suatu Pendekatan Praktik. Jakarta : Rineka Cipta.

Banurea, Nurhasanah. 2018. Pengaruh Model Pembelajaran Somatic, Audtory, visualization, aintellectualy (SAVI) Terhadap Kemampuan Menulis Naskah Drama Siswa Kelas XI SMA Swasta Yapim Biru-biru. Medan UNPRI.

Dalman. 2015. Keterampilan Menulis. Jakarta : Rajagrafindo Persada.

Febri, Tina. Dalam http:// www.blognet.com/2015/mengenai pengertian teks.html di akses pada tanggal 25 januari 2018.

Gorys, Keraf. 2000. Argumentasi dan Narasi. Jakarta: PT Gramedia Pustaka Utama

Poerwadamirta. 2003. Kamus Besar Bahasa Indonesia. Jakarta: Balai Pustaka

Riyanto, Yatim. 2009. Paradigma Baru Pembelajaran. Jakarta: Kencana 2010. Sudjana, N. 2002. Metoda Statistika. Bandung: Tarsito.

Shoimin, Aris.2006.68 Model Pembelajaran inovatif dalam kurikulum 2013. Yogyakarta: ArRuzz Media.

Sugiyono. 2012. Metode Penelitian pendidikan. Bandung: Alfabeta

Sumiati. 2018. Metode Pembelajaran. Bandung: Cv Wacana Prima

Sudjana, N. 2005. Metoda Statistika. Bandung: Tarsito.

Situmeang, Saripah. 2015. Upaya Peningkatan Keterampilan Menulis Paragraf Persuasi Melalui Metode Pembelajaran kontekstual Di Kelas X SMA Swasta Free Methodist Medan.

Tarigan, Henry G. 2008. Menulis. Bandung: Angkasa Bandung. 